\title{
Adoption of Resource Conserving Technologies by Farmers in the Rice Wheat Systems of Pakistan
}

\author{
Tahseen Jafry ${ }^{1, *}$, Ashraf Poswal ${ }^{2}$, Bushra Raza $^{2}$ Ahmad $^{2}$, Gulam Ali $^{2}$ \\ ${ }^{1}$ Glasgow Caledonian University, Cowcaddens Road, Glasgow, G4 OBA, United Kingdom \\ ${ }^{2}$ CABI Pakistan, Opposite 1-A, Data Gunj Baksh Road, Satellite Town, Rawalpindi-Pakistan \\ *Corresponding Author: T.Jafry@gcu.ac.uk
}

Copyright $@ 2013$ Horizon Research Publishing All rights reserved.

\begin{abstract}
The adoption of new resource conserving technologies (RCT) (such as the zero till drill) which impacts on crop yields and/or household budgets is significant to the livelihoods of resource-poor farming families in terms of their food security and income. This study was conducted with farmers from four socio-economic groups, i.e. landless, marginal, subsistence or food surplus/cash cropping in 2 villages in Shekhupura district and 2 villages in Sialkot district of Pakistan to determine their ability to adopt zero till drills as an approach to improving wheat production and thereby increasing their food security status. Participatory semi-structured interviews and focus group discussions were used to collect information. Our findings indicate that it is those farmers who have sufficient land to guarantee household food security throughout the year that can take the necessary risk of adopting new technologies such as the zero till drill. But that this finding was not uniform across all the villages. Many landless and marginal farmers were confused regarding the benefits of using the zero-till drill for wheat production. Farmers who had experienced using the zero-till drill complained of soil compaction, increased pest problems in the following rice crop and lack of back-up support It was recommended that more emphasis is put on disseminating information concerning RCTs at gatherings such as Haweli that involve all farmer groups but especially marginal farmers. These farmers could be organised into Citizen Community Boards so that they can access government funding for agricultural equipment, including zero-till drills which would allow the sharing of equipment especially by the poorest groups.
\end{abstract}

Keywords Adoption,Rice-Wheat Systems, Zero-Tillage

\section{Introduction}

Rice and wheat are grown sequentially in a mainly irrigated, double cropping pattern in the Indo-Gangetic plains of South Asia on about 13.5 million hectares of land in Bangladesh, India, Nepal and Pakistan [9]. It is a major cropping system for sustaining food security in the region and there are millions of farmers and agricultural workers dependent on this system for employment and livelihoods. Similarly the rice-wheat system of Pakistan is spread over 2.1 million hectares and represents nearly $9 \%$ of the global rice-wheat system. Nearly three-fifths of Pakistan's rice-wheat area lies in the Punjab province where about 10 million people are directly involved. In Punjab, rice-wheat cropping sequence is practiced in the Kalat tract, mainly covering three main districts, Gujranwala, Shekhupura and Sialkot. Rice-wheat is also practiced in the periphery districts (i.e. Lahore, Gujrat and Mandi Baha-ud-din) of these three main districts. From a national perspective, rice is Pakistan's export crop while wheat bears food security concerns, as wheat is the main staple food of Pakistani population.

The productivity of this important system has declined or stagnated during the last decades [1,10]. Decline in productivity of this important cropping system is significant in terms of sustainability of food security [11]. To keep pace with the changing requirements of the ever growing population under the free trade era of globalization there are demands for the rapid adoption of new technologies and methods to help increase production of wheat. The system diagnostic studies conducted by [2] and [11] estimated big yield gaps between the potential and actual wheat yields realized by the farmers. Land preparation practices peculiar to the rice crop along with its planting time conflicts with the following wheat crop and are determined as major yield limiting factors. Flooded and puddle soil required by rice as compared to well drained conditions necessary for wheat [6] is one such example of these system conflicts. Late rice harvest, soil structure and plant residues creates difficulties for the preparation of a good seedbed for wheat crop [2]. This results into late planting of wheat and farmers usually use broadcast methods for wheat sowing. Rainfall, at the time of land preparation, further delays planting of wheat by 2-3 weeks in the area [1]. Ref [3] and [7] have reported that delaying the planting of wheat after mid November caused loss in grain yield at the rate of one percent, per day, per hectare. The Rice Wheat Consortium (RWC) for the Indo 
Gangetic plains, (involving International Agricultural Research Centres and National Agricultural Research Organizations) developed and promoted a number of technologies that increase farm-level productivity, conserve natural resources and limit negative environmental effects in order to address these problems. The Rice-Wheat Consortium (RWC) for the Indo-Gangetic Plains (IGP) was founded in 1994 as an eco-regional programme of the CGIAR in response to concerns about the sustainability of the rice-wheat systems of South Asia.

To improve productivity in South Asia's rice-wheat cropping systems, zero-till (ZT) methods were introduced into the region to encourage timely planting of wheat after rice. In Pakistan, adoptive research, designed to make zero-tillage methods suitable for local conditions, were initiated during the mid 1980s following the importation of a prototype drill from New Zealand. With concerted long term efforts by researchers from Pakistan Agricultural Research Centre (PARC), researchers from International Maize and Wheat Improvement Centre (CIMMYT), and local machinery manufacturers, an effective zero-till seed drill was developed for local manufacture. The adoption of this technology which has important implications for all farmers involved in rice-wheat farming systems was the focus of this research. Specifically to address and determine: Who (which farmers) have benefitted from the use of the machines? What have been the benefits? and What is the outlook for wider adoption?

Background to introduction of zero tillage machines

From 1995 to 1998, the Department of On Farm Water Management (Pakistan) had been working on promoting the zero tillage technology. They did this by revamping old machines that had been given provided in the 1980's and giving them out to farmers. In 1999, a 3 year DFID (Department of International Development, UK) funded project (covering Pakistan, India and Nepal) further promoted the use of this technology. This was followed by another project in 2000 from Massey University with New Zealand funding (which covered Uzbekistan and Pakistan) for 2 years. In 2001 another New Zealand Aid funded project (covering Pakistan and Nepal) for 3 years was sanctioned and in 2001 the Asian Development Bank and New Zealand Aid funded another project for 3 years to disseminate further.

\section{Materials and Methods}

\subsection{Case Studies}

Case studies were conducted with 4 groups of farmers; cash-cropping/big farmers, subsistence, marginal and landless on the use of the resource conserving technology the zero till drill. Two villages in each of two districts were chosen for this study, i.e. Pindi Rateen Singh and Khokhar ki Mallian villages in Shekhupura district and Bodha Goraya and Malomay villages in Sialkot district. The villages of
Khokar ki Malian and Bodha Goraya are non-adopted villages, which means that the machinery has not been introduced here. The other two villages are the initial core villages where the zero tillage technology was initially introduced under various agricultural programmes; in 1998 (Malomay) and 1999 (Pindi Rateen Singh) - these villages are also where agricultural extension workers have introduced new rice and wheat varieties through demonstration plots. This study captures the impact that the zero tillage technology has made to these villages and provides an overview of the issues between adoption and non-adoption amongst farmer groups. The location of the villages can be seen in Figure 1.

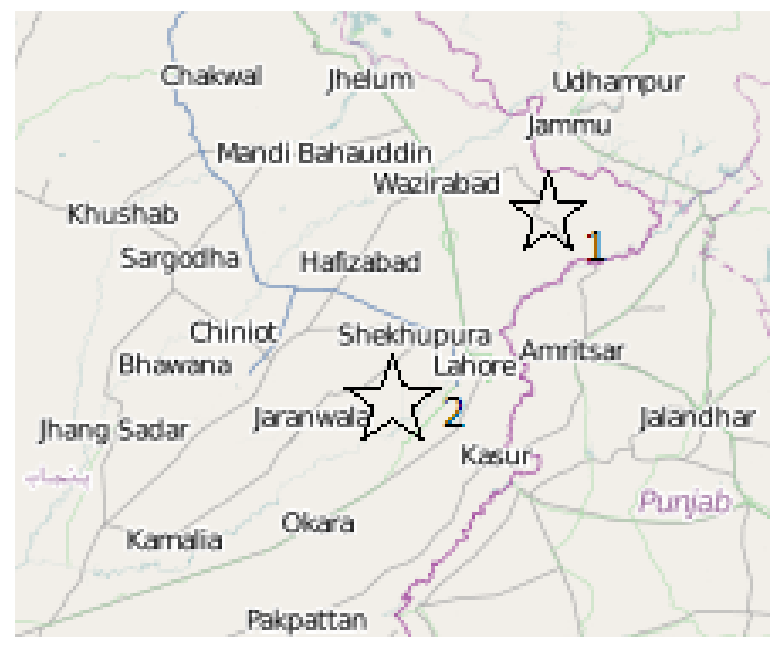

(C) OpenStreetMap contributors

Figure 1. Location of study villages in Pakistan $(1=$ Sialkot district villages; $2=$ Shekhupura district villages)

Using a Livelihoods Approach to Target the Poorest Farmers

The following socio-economic categories were drawn up according to their ability to take risk: in this case adopting and not adopting the technology.

- Landless/food deplete farmer: Must rent land or do paid labour to get food and pay for other necessities. Cannot take any risks.

- Marginal/food deficit farmer: Has insufficient land to achieve household food security. Regular shortage of food and cash. Must do labour in order to buy additional food, inputs and other basic necessities. Can enter a downward spiral very easily. Cannot take any risks.

- Subsistence/self-sufficient farmer: Has sufficient land to meet basic food needs under normal conditions. May need to do labour to pay for inputs and other necessities (including school fees). Remains vulnerable to economic and environmental shocks. Is risk averse.

- Food Surplus/cash cropping farmer: Has sufficient land to guarantee household food security. Able to produce surplus grain and cash crops for sale to buy inputs, send children to school and accumulate 'middle class' assets, e.g. bicycle, TV, electric fan. Able to take risk.

Semi-structured interviews and focus group discussions were conducted with the farmers from each of these groups 
in all the villages in order to determine the answer to the following research question: what are the reasons for using or not using the zero-tillage machine?

In total 73 farmers were interviewed. Table 1 contains a breakdown of the types of farmers interviewed in the 4 villages. Equal numbers of farmers in each of the categories could not be achieved due to non-availability of farmers in each of the locations because of their engagement with other livelihood activities. However, through the use of case study methodology a good holistic understanding of the issues were achieved.

Table 1. Number of Farmers Interviewed in Study Villages

\begin{tabular}{|c|c|c|c|c|}
\hline & $\begin{array}{c}\text { Malomay } \\
\text { Village }\end{array}$ & $\begin{array}{c}\text { Bodha } \\
\text { Goria }\end{array}$ & $\begin{array}{c}\text { Pindi } \\
\text { Rateen } \\
\text { Singh }\end{array}$ & $\begin{array}{c}\text { Khokar ki } \\
\text { malian }\end{array}$ \\
\hline Landless & 0 & 2 & 3 & 3 \\
\hline Marginal & 3 & 11 & 6 & 6 \\
\hline Subsistence & 8 & 7 & 6 & 6 \\
\hline $\begin{array}{c}\text { Cash } \\
\text { Cropper }\end{array}$ & 4 & 2 & 3 & 3 \\
\hline
\end{tabular}

Before conducting the case studies a site meeting in the research villages Khokar ki Malian, Pindi Rateen Sing and Bodha Goraya were convened. The investigatory team interacted with the farmers and determined the programmes and modalities for conducting the impact assessment. Knowledge and information, introduction and testing of new RCTs were discussed with the farmers. The area coverage and constraints faced by the farmers adopting RCTs was discussed in detail. The impact of RCTs on resource saving, including time, cultural practices and input, was investigated and bottlenecks were discussed and documented. The interview data was synthesised to identify key patterns, themes, issues and any conflicting evidence. This information was compiled as case studies.

\subsection{Results of the Village Case Studies}

Presented below are the findings of the impact studies undertaken as four case studies.

\section{Case Study 1 Khokar ki Malian, Shekhupura District}

This is a non-adopted village of the project. The farmers here have not had exposure to this machine in their village and therefore they do not use it. However, in the neighbouring village of Soa ki Malian there has been a farmer using zero tillage machine. The farmer in Soa ki Malian used it in 2001-02 then left it in 2003-2004 and is now again using it. His reason for using it initially was that it was being provided by a research and development project it was free. The machine was then taken away and so he could not use it. However, the machine is being promoted by another organization so he has access to it again and does use it. Farmers from Khokar ki Malian have seen the machine being used in this neighbouring and other villages, such as, Farukabad (25km away), Muriedkay (16km away),
Kathianwala ( $4 \mathrm{~km}$ away). But the farmers who are using the machine in these areas are big landholders who have bought the machine from Daska and do not lend it on hire basis. Daska is the nearest town that manufacturers zero tillage machines, which is approximately $80-90 \mathrm{~km}$ away from Khokar ki Malian. There are no suppliers or dealers of this machine in Shekhupura district. All the farmers interviewed expressed interest in this machine but said that their main constraints were finance, access to the machine and its timely availability. The tractor owners (cash croppers) in Khokar ki Malian say they cannot afford to buy zero tillage machines. Given this scenario a number of avenues for further dissemination were identified and explored further.

- Options to improve access. The farmers from Khokar ki Malian could link with NGOs to develop a Citizen Community Board (CCB) machinery pool group. This is where the government can provide $80 \%$ subsidy to the group and the farmers provide $20 \%$ of the remaining funds in order to obtain the improved machines for farm work.

- Supply centers/hire schemes. All landless and marginal farmers are afraid the larger farmers will get preference over them and so they will not benefit from hire schemes. All larger farmers, considered here as cash croppers and subsistence farmers who own land, stated that they are more risk averse than landless and marginal farmers and able to take more risk e.g. in trying a new technology which may work or not under their field conditions. As schemes they would need to be careful managed to ensure that the needs of landless and marginal farmers could be met.

- Promotion schemes:

(a) Farmer Field School (FFS) of zero tillage machine at Soa Ki Malian

In order to promote the use of zero tillage machines in the area, a farmer field school at Soa Ki Malian was established. The field school set up comparison plots i.e. under zero tillage and under conventional method for demonstration to farmers. The farmers visited the plot every 14 days to see how the crop was establishing and progress was being monitored. The feedback from farmers was very encouraging. The farmers felt that that they would get a better yield compared to the conventional plot.

(b) Training of Trainers (TOT) plot

A training of trainers plot at the Rice Research Station, Kalashah Kaku, Shekhupura was established. The purpose of the TOT plot was to provide participatory training to NGOs, Government extension staff, farmers groups on the zero tillage technology. The reason for this was that the TOT plots could be used to train others so that they could pass on information to their farmers via FFS so reaching many more areas and farmers.

\section{Case Study 2 Pindi Rateen Singh, Shekhupura District}

The machine was initially introduced to a Landlord Nasreen Begum for demonstration purposes in 1999 and where farmers could come and observe the plots. The farmers in this village initially had access to the machine in 2000 when it was introduced by the On Farm Water 
Management Department (OFWM). The machine was kept in the OFWM office in Kamokay, $30 \mathrm{~km}$ away. Preference was given to larger farmers (subsistence and cash croppers) and farmers they were familiar with. The landless and marginal farmers were sidelined. The farmers used the machine in 2000-2001 and 2001-2002. In 2002-2003 fewer farmers had access to the machine. In 2003-2004 farmers did not get the machine at all. The machines were not in the office, probably being used by farmers elsewhere. The farmers in this village did not have access to the machine at the right time and so they converted back to using the conventional method.

There are other zero till machines in the area: Chak No 26 - (1 km away) where there is 1 machine and Joyanwala $(8 \mathrm{~km}$ away) where there are 6 machines, 2 owned by subsistence farmers and 4 owned by big farmers.

In Pindi Rateen Singh in 2004-2005 one big farmer in the village, Malik Shahbaz (who has 15 acres of his own plus he rents 145 acres) owns a ZT machine and has hired it out to a few farmers. In 2004-2005, 6 subsistence farmers have hired the ZT machine to use in their fields. The following issues were identified about the use of the machine by these farmers.

- Drainage - ZT is a problem on clay loam soil especially when there has been heavy rainfall. When there is heavy rainfall, the soil becomes hard and does not allow the water to penetrate into the ground. The water is left standing in the wheat field. Wheat does not grow well in water-logged soil. The problem seems to one of poor drainage.

- Short spike length - this becomes an issue when farmers put too much seed into the field than the recommended amount. If the farmers use $60 \mathrm{~kg} /$ acre there is not enough space per plant and results in short spike length but if they sow 40 $\mathrm{kg} / \mathrm{acre}$ there is no problem.

- Rice stem borer is a problem as indicated by a number of farmers.

- Discouragement from Dept of Agricultural Extension - the agricultural extension staff came to the village to discourage farmers from using the machine because of soil compaction and short spike length.

One big farmer who has clay loam soil and has been using zero tillage for 3 consecutive years indicated that there was no difference in wheat production between conventional and zero tillage methods. But there were differences in time saving and seed and fertilizer used. He did also observe short spike length. This finding was confirmed by 2 other big farmers interviewed.

\section{Case Study 3 Bodha Goraya, Sialkot District}

This is a non-adopted village. The nearest ZT machine to this village is in Chalaki Garia which is $1 \mathrm{~km}$ away. There is one machine in Chalaki Garia which is owned by a big farmer. He uses it on 18 acres out of his 30 acres. He has been using it since 2002. There is another machine in Dugria, which is $3 \mathrm{~km}$ away. It is owned by a big farmer who has 40 acres. He hires it out to others for 6-700 Rs/acre (including tractor). Other than these two villages, there is no other village in the neighbouring areas that have $\mathrm{ZT}$ machines.

One big farmer in Bodha Goraya hired the machine from Chalaki Garia in 2003-2004 for 500 Rs per acre. He is now interested in growing potatoes rather than rice/wheat so does not need the ZT machine. When he did use it in 2003-2004, the other farmers (landless and marginal) from the village told him not to because it will destroy his land and the birds will come and eat the seeds. But now they think it is good because they know of others who have used it outside of their village. The problem is that they cannot afford the hire charges.

In Bodha Goraya there are 600 households and 14 tractors. The tractor drivers cannot afford to invest in buying a machine. They are also not guaranteed a rental market even if they did buy the machine so they are not willing to take the risk.

\section{Case Study 4 Malomey, Sialkot District}

The ZT machine was introduced in this village in 1998 by a project. It was also promoted by the On Farm Water Management Dept. The farmers contributed $50 \%$ share towards the purchase of a ZT machine, the other $50 \%$ came from the project. The machine is kept in the village farm service center. The farmers (subsistence and cash croppers) used the machine in 1999 and 2000. The responses from the farmers interviewed are summarised below. This village has both clay and silt soil. Landless and marginal farmers cannot financially afford to use this machine, have plots of land that are too small.

On clay loam soil:

- Uneven land - the soil is not level because the rice is transplanted manually and the stubbles are left in the ground, this type of uneven land is not good for zero till machine.

- The weight of the combine harvester wheels running over the land makes the soil uneven.

- Insect infestation, mainly grasshoppers, which eat and cut the crop.

- Clay loam soil does not allow the root system to develop properly which results in plant lodging problems.

- Small spike length which is an indication of less yield.

When the farmers used the drill on silt soil there were no problems like the ones mentioned above. $60 \%$ of this village has clay loam soil whilst $40 \%$ has silt loam soil. The total land holding is 1400 acres out of which $80 \%$ is for rice and wheat, $20 \%$ is for vegetables and sugar cane. However, none of the farmers interviewed want to use the ZT, they prefer to use the rabi drill instead even though they recognise that under some soil types the ZT machine is useful. They consider the rabi drill gives a better yield. Every year farmers use the rabi drill inside and outside the village.

In 2002, 7 farmers from outside the village came to take the zero till drill, after that no one has come. The farmers want to sell it but no one wants to buy it. This may also be because it has not been used since 2000 and it is not in good condition.

The farmers also indicate that the On Farm Water Management Dept have given false statements to them, e.g. 
that 300 acres are under zero till when it is not and also the Extension Dept do not provide any backup support.

The farmers are aware of machines that are sold in Daska. But they believe that these machines are sold to farmers who have saline soil or silt soil not clay loam soil.

One of the reasons given for non-adoption of the machine in these villages is the use of early maturing varieties. Some of the farmers for the last 2-3 years have been growing early maturity rice varieties and so they have enough time to prepare the land by conventional methods.

\section{Discussion}

The villages used for this research project are classified into adopted and non-adopted; non-adopted means that the farmers have not had exposure to the machine in the village and thus have not used it. Adopted means that the machine has been introduced to the village under various schemes and farmers are either using it, have used it and are not using it any longer, or choose not to use it after all.

In the non-adopted villages, all farmers indicated that access and non-availability at the right time of the season is the reason why they are labelled as a non-adopted village. There is expressed interest from all farmer categories in these non adopted villages but there are severe financial constraints; the majority of the farmers are marginal and subsistence and cannot afford to buy the machine. Big farmers express concern in investing in these machines. However, it is not just financial constraints that seem important, the research findings highlighted the fact that lack of access to knowledge, information and awareness about the technology is a barrier to adoption. As indicated in Bodha Goraya, there are misconceptions regarding the benefits of the machine which are based on traditional beliefs rather that scientific evidence. These beliefs cannot be underestimated which confirms the need for communication and dissemination of new knowledge and information.

In the adopted villages, many issues were raised concerning the impacts of using the machine which were raised by the subsistence and cash croppers who are the only groups to have used these machines, these included: poor drainage, soil compaction, increased infestations with rice stem-borer, timely availability and disagreements between the Agricultural Extension Dept and the Water Management Dept on whether or not to recommend the use of the machine. The issue of increased stem-borer activity in the following rice crop has been discussed in a number of studies. The farmers' experience of an increase, in this research, confirms the findings by [8] and [12]. However, according to Hobbs (personal communication.) there are 2-3 million hectares of no-till wheat now being produced across the Indo-Gangetic plain and so far there have been no reports of any massive outbreaks of this pest. Considering that the larvae survive in the base of the rice stubble, very few are able to survive until March or April if wheat is grown, irrigated and fertilized according to recommended practices. The problem usually only arises in fields left fallow and un-irrigated after a rice crop. It has been found that when stubble is left in the field it provides a habitat for beneficial insects that prey of the larvae. Although this issue/problem has been debated many times by scientists, the fact that farmers, in these adopted villages still remain unclear about the impact of zero tillage on the rice stem borer suggests the need for further farmer participatory research, comparing both tillage practices and cropping systems on the over wintering of this pest.

On the issue of compaction, it is considered that this is not a problem in rice-wheat systems. As long as the fields are ploughed and puddled for the next rice crop, any compaction or plough pan would be there as a result of this puddling anyway. Ref [5] working in highland areas of Mexico found that compaction and declining yields are only problematic if all the residues are removed, however if sufficient residue from either a cereal or a cover crop remains, compaction does not occur and yields remain high. An earlier DfID-funded project which investigated soil fungi and nematodes under zero tillage systems in Pakistan and India concluded that the adoption of this technology did not adversely affect soil health [4].

\section{Conclusion}

The results, although pertaining to the specific project villages and in particular to the number of farmers interviewed have revealed some significant findings. It was observed that for farmers, in every category, the most important agenda is to have a technology which should be suitable for their soil type, be of low input cost, be accessible and result in increased productivity. Access to knowledge and information plays an important and significant part in helping farmers come to decisions about whether to use RCT or not. This study revealed that it is the better off farmers (subsistence and cash croppers) who initially benefit from zero tillage machines and indeed this technology has had widespread impacts on the rice-wheat farming system of the Indo-Gangetic Plains probably via this means. However, this study also shows that the landless and marginal farmers are the ones who are 'left behind'. This exclusion means that new technologies do not reach them. To surmise, providing access to these new technologies (physically and through new knowledge and information) to all types of farmers will help them in making decisions regarding the adoption or non-adoption of a new technology.

\section{Acknowledgements}

The authors wish to acknowledge the funding support from the Department for International Development (UK) and CABI UK for funding this research. The authors would also like to acknowledge the CGIAR Research Center, CIMMYT (International Maize and Wheat Improvement 
Center, Mexico) in its capacity to act as facilitators in conducting the field work.

\section{REFERENCES}

[1] M.Aslam, A. Majid, N.I. Hashmi, P.R.Hobbs, Improving Wheat Yield in the Rice-Wheat Cropping System of the Punjab through Zero Tillage, Directorate of Agricultural Information, Punjab, Lahore (Pakistan), Pakistan Journal of Agricultural Research, Vol 14, No 1, pp 8-11, 1993.

[2] D.Byerlee, A.D. Sheikh, M. Aslam. P.R. Hobbs, Wheat in the Rice Based Farming System of Punjab: Implications for Research and Extension, Pakistan Agriculture Research Center/CIMMYT Collaborative Programme, Islamabad, 1984.

[3] A.S.Randawaha, R.S. Jolly, S.S. Dhillon, Effect of Seed Rate and Row Spacing on the Yield of Dwarf Wheat under Different Sowing Dates, Elsevier, Field Crops Research, Vol 32, No 2, pp 87-96, 1979.

[4] E.Duveiller, J.Bridge, M.Rutherford, S.Keeling, Soil Health and Sustainability of the Rice-Wheat Systems of the Indo-Gangetic Plains, Rice-Wheat Consortium for the Indo-Gangetic Plains, New Delhi, Rice-Wheat Consortium Paper Series, Vol 16, 2004.

[5] B.Govaerts, K.D. Sayre, J. Deckers, Stable High Yields with Zero Tillage and Permanent Bed Planting?, Elsevier, Field Crops Research, Vol 94, No 1, pp 33-42, 2005.

[6] P.R.Hobbs, Agronomic Practices and Problems for Wheat
Following Cotton and Rice, CIMMYT, Proceedings of International Symposium, Mexico, D.F., pp273-277, 1985.

[7] P.R. Hobbs, C.E. Mann, L. Butler, L. Perspective on Research Needs for Rice Wheat Rotation, CIMMYT, In A.R.Klatt (ed). Wheat Production Constraints in Tropical Environments, Mexico, D.F., pp 197-211, 1988.

[8] C.Inayatullah, Ehsan-ul-Haq, Ata-ul-Mohsin, A. Rehman, P. R. Hobbs, Management of Rice Stemborers and the Feasibility of Adopting No Tillage in Wheat, Pakistan Agricultural Research Council, Islamabad, Pakistan, 1989.

[9] J.K. Ladha, K.S. Fischer, M. Hossain, P.R.Hobbs, B. Hardy B, Improving the Productivity of Rice-Wheat Systems of the Indo-Gangetic Plains: A Synthesis of NARS-IRRI Partnership Research, International Rice Research Institute (IRRI) Discussion Paper No. 40, IRRI, Los Baños, Philippines, 2000.

[10] M.S.Randhawa, S.S. Dhillon, D.Singh, Productivity of Wheat Varieties as Influenced by the Time Sowing, Punjab Agriculture University, Journal of Research, Vol 18, pp 227-233, 1981.

[11] A.D.M.Sheikh, M.Zubair, M. Asif, Barriers in Enhancing the Productivity of the Rice- Wheat Farming System of the Punjab, AERU, NARC, Technical Report 2000. 75pp, 2000.

[12] S.K.Srivastava, R.Biswas, D.K. Garg, B.K. Gyawali, N.M.M. Haque, P. Ijaz, S. Jaipal, N.Q. Kamal, P. Kumar, M. Pathak, P.K. Pathak, C.S. Prasad, M. Ramzan, A.Rehman, M.Salim, A.Singh, U.S.Singh, S.N.Tiwari, Management of Stemborers of Rice and Wheat in Rice-Wheat Systems of Pakistan, Nepal, India and Bangladesh, Rice-Wheat Consortium for the Indo-Gangetic Plains, New Delhi India, Rice-Wheat Consortium Paper Series 17, pp204, 2005. 